\title{
Caramuru, o mito: conquista e conciliação
}

\section{David Treece}

Tradução de Marcos César de Paula Soares

\begin{abstract}
Resumo: Este ensaio procura traçar a história do mito do Caramuru, considerando que as versões de Santa Rita Durão e de outros expressam atitudes diversas em relação à colonização e à nacionalidade. Fundamental para essa história é a reavaliação importante que o mito sofreu no século XIX, quando o romantismo e a ideologia liberal rejeitaram a noção de conciliação racial que se situa no centro da lenda do Caramuru. Palavras-chave: Caramuru, Santa Rita Durão, romantismo.
\end{abstract}

\begin{abstract}
This essay attempts to trace the history of the Caramuru myth, whereas the versions of Santa Rita Durão and others express various attitudes related to colonization and nationality. The important reevaluation of the myth in the nineteenth century was essential to the story. At that time, Romanticism and the liberal ideology rejected the notion of racial conciliation that lies at the heart of the legend of Caramuru. Keywords: Caramuru, Santa Rita Durão, Romanticism.
\end{abstract}




\section{Introdução}

No primeiro século da colonização brasileira surgiram diversas figuras que adquiriram uma qualidade mais ou menos lendária devido ao longo contato com a terra inexplorada e seus habitantes. A fértil narrativa do alemão Hans Staden sobre o canibalismo entre os indígenas foi produto de alguns meses em que ele foi prisioneiro dos índios Tupinambás de Santo Amaro, uma ilha ao sul do Rio, próxima do porto de Santos. A estada de João Ramalho entre os índios Goianás-Tupiniquins de São Vicente, capital da província mais ao sul do país, já foi bem mais pacífica e produtiva: sobrevivente de um naufrágio, Ramalho foi adotado pela tribo, que ficou impressionada com suas habilidades guerreiras, e se consagrou como o primeiro patriarca branco do Brasil. Seus filhos mamelucos formaram a base da sociedade mestiça paulista, cujos representantes mais famosos eram os bandeirantes. Outra figura mais enigmática, conhecido como O Bacharel, teve um papel semelhante em Cananeia, um pouco mais ao sul da costa, nas primeiras décadas do século XVI. Dois ingleses que naufragaram em épocas diferentes na costa brasileira, Peter Carder e Anthony Knivet, sobrevivem em livros de história devido às suas tentativas de aprimorar as técnicas militares dos índios. ${ }^{1}$ A história de Diogo Álvares Caramuru combina elementos de todos esses casos e constitui outro exemplo da fascinação europeia pelos exploradores e pelos limites do mundo conhecido. Porém, isso não explica a razão pela qual o mito do Caramuru, na sua forma relativamente complexa, tenha atraído tamanha atenção por tanto tempo para dar origem a mais de uma obra erudita de literatura.

Essa história de um marinheiro português que naufragou na costa da Bahia, foi salvo de ser executado pelos indígenas locais e se casou com a filha do chefe da tribo é mais bem conhecida, quer dizer, é conhecida quase exclusivamente através do poema Caramuru, escrito pelo teólogo Frei José de Santa Rita Durão no século XviII. ${ }^{2}$ Entretanto, uma análise atenta desse e de outros textos mostra que o poema é uma distorção extrema do mito original, condicionada por circunstâncias históricas e ideológicas peculiares. Em narrativas semilendárias desse tipo, os detalhes da história apresentam quase tantas variações quanto o número de versões. É importante apontar que os cronistas e historiadores posteriores também são tão responsáveis quanto os escritores de ficção por mudanças de ênfase e pormenor. Este ensaio pro-

\footnotetext{
HEMMING, John. Red gold. The conquest of the Brazilian Indians. London: Macmillan, 1978, p. 29-33 e $42 \mathrm{f}$.

Frei José de Santa Rita Durão: Caramuru, poema epico do descubrimento da Bahia (Lisboa: Regia Officina Typografica, 1781). Salvo indicação contrária, todas as citações são desta edição.
}

308 • TREECE, David. Caramuru, o mito: conquista e conciliação 
cura traçar a evolução histórica do mito do Caramuru e considera como as versões de Santa Rita Durão e de outros expressaram atitudes diversas em relação à colonização e à questão da nacionalidade. Fundamental para essa evolução é a reavaliação importante que o mito sofreu no século XIX, quando o romantismo e a ideologia liberal rejeitaram a noção de conciliação racial que se situa no centro da lenda do Caramuru. A partir da nova perspectiva histórica dessas ideias, a realidade do Brasil colonial, uma realidade de conflito trágico, tirania política, escravidão e carnificina, não ia ao encontro da noção da união harmoniosa entre o homem branco e o índio.

\section{Narrativas históricas e versões literárias}

Para mapear o mito do Caramuru serão feitas referências a cinco obras literárias inspiradas pela história e a sete narrativas históricas representativas dos principais estágios culturais e políticos da história do Brasil, a primeira delas particularmente importante como fonte para as versões ficcionais.

Uma das primeiras e mais elaboradas menções ao mito é a do colono Gabriel Soares de Sousa: seu Notícia do Brasil foi publicado em 1587.3 Outros detalhes aparecem nas obras de dois clérigos do século xvir: a História do Brasil 1500-1627, de Frei Vicente do Salvador, ${ }^{4}$ e Chronica da Companhia de Jesu do Estado do Brasil, de Simão de Vasconcellos. ${ }^{5}$ No século xix, o historiador Francisco Adolfo de Varnhagen, em sua pesquisa sobre os principais expoentes do mito ("O Caramuru perante a história”), enfatiza a importância de Simão de Vasconcellos para a ordenação dos acontecimentos da história numa estrutura coerente: "É possível que Vasconcellos, recebendo a tradição já arranjada a modo de romance, a concertou como poude para narrar envolvida nas formas históricas estes sucessos". ${ }^{6}$ A versão mais elaborada e altamente retórica de Sebastião da Rocha Pitta em História da America Portugueza dá o tom literário para o século XviıI e para Santa Rita

7

SOARES DE SOUZA, Gabriel. Notícia do Brasil. São Paulo: Martins, 1949, 3 vols, I. 1, cap. XXVIII.

SALVADOR, Frei Vicente do. História do Brasil (1500-1627). São Paulo: Melhoramentos, 1965, 126 f., p. 160.

VASCONCELLOS, Simão de. Chronica da Companhia de Jesu do Estado do Brasil. Lisboa: Officina de Henrique Valente de Oliveira, Impressor dei Rey N. S., 1663, p. 35-40.

VARNHAGEN, Francisco Adolpho de. "O Caramuru perante a historia". Revista do Instituto Histórico e Geographico Brazileiro, 3 (n. 10), p. 129-52, Rio de Janeiro, 1848.

ROCHA PITTA, Sebastião da. História da America Portugueza desde o anno de mil e quinhentos do seu descobrimento até o de mil e setecentos e vinte e quatro. Lisboa: Francisco Arthur da Silva, 1880, p. 29-31.

Teresa revista de Literatura Brasileira [12|13]; São Paulo, p. 307-344, 2013 • 309 
Durão. Para efeito de comparação, tomei também uma narrativa estrangeira do livro History of Brazil, de Robert Southey. ${ }^{8}$ Varnhagen foi o historiador oficial do Segundo Reinado e um dos primeiros expoentes da "historiografia erudita" no Brasil. Seu ensaio "O Caramuru perante a história" tem como principal objetivo provar a falsidade histórica do relato da visita de Diogo e sua esposa à Europa. Em seu monumental História geral do Brasil, ${ }^{9}$ Varnhagen retoma o incidente mais conhecido da história, a aventura de Diogo com seu mosquete e seu batizado como "Caramuru". Todavia, ele dedica mais espaço a um aspecto com ressonâncias históricas mais amplas, a saber, o caráter político do papel desempenhado por Diogo na Bahia. Mais recentemente, as explicações de Pedro Calmon em História do Brasil ${ }^{10}$ se baseiam em pesquisas sobre materiais dos arquivos municipais da Bahia. Calmon se refere à "Paraguaçu histórica", embora outras fontes indiquem que o nome não aparece em nenhum dos documentos antigos e que teria sido inventado por Vasconcellos em $1663 \cdot{ }^{11}$ Calmon inicia assim sua narrativa: "É misteriosa a origem de Diogo Álvares", como se fosse forçado a reconhecer a natureza essencialmente a-histórica e fluida do mito.

Assim, a história do Caramuru desafia as tentativas dos historiadores de defini-la como um fato uniforme e imutável. Apesar da aparente interdependência das diferentes versões, é impossível identificar um único sentido de tradição ou continuidade interna no desenvolvimento da lenda. Na verdade, todos os autores desde o século XviII costumam voltar-se para Gabriel Soares e Simão de Vasconcellos como as fontes mais confiáveis ou, para talvez ser mais preciso, como as versões mais básicas, mesmo coerentemente formuladas, e, portanto, aquelas mais disponíveis para adaptações ideologicamente informadas.

Publicada em 1781, a obra de Santa Rita Durão, Caramuru, poema epico do descubrimento de Bahia, é uma dentre as diversas tentativas nos séculos XVIII e XIX (cf. O Uraguai, A confederação dos Tamoios, Os Timbiras) de descobrir um acontecimento na história do Brasil e uma figura de estatura suficiente que expressassem um sentimento de nacionalidade assim como Os lusíadas havia feito para Portugal no século xvi. Grande parte dos críticos observou que o conservadorismo estilís-

SOUTHEY, Robert. History of Brazil. London: Longman, Hurst, Rees and Orme, 1810, $30 \mathrm{f}$.

VARNHAGEN, Francisco Adolpho de. História geral do Brasil antes da sua separação e independência de Portugal. 7. ed., 2 vols. São Paulo: Melhoramentos, 1959, l, p. 200-3, 237-44. 
tico do poema e suas monótonas passagens históricas, escritas de modo a aderir às convenções do gênero estabelecidas pelos Lusíadas, diminuíram seu interesse e valor. Entretanto, nenhum deles se deu conta de que o poema é acima de tudo notável por sua perspectiva veementemente católica, sua consequente subversão de diversos elementos fundamentais do enredo tradicional e sua visão condenatória dos indígenas. Isso tudo se torna ainda mais interessante no contexto das ideias europeias da época, nas quais a imagem do homem primitivo tinha conquistado um estatuto cada vez mais significativo sob o impacto de figuras como Montaigne, Lafitau, Montesquieu e Diderot, alcançando seu clímax com o "homme naturel" de Rousseau e a publicação do Discours sur l'origine et les fondements de l'inégalité parmi les hommes em 1755.

A reação peculiar de Santa Rita Durão pode em grande parte ser explicada pelas circunstâncias imediatas da composição do poema e pelos principais conflitos ideológicos para os quais elas apontam. O Caramuru foi escrito, assim como O Uraguai doze anos antes, como resultado da expulsão dos jesuítas de Portugal e das colônias, ordenada pelo déspota esclarecido Marquês de Pombal, que governava o país desde 1755. Além de privar a Ordem do poder espiritual no Império, Pombal destituiu os jesuítas de uma de suas atividades seculares mais importantes no Novo Mundo. Em 1755, a administração dos índios nas missões para sua conversão ao cristianismo e sua inserção no mercado de trabalho foi transferida para os diretórios controlados pelo governo. Isso se deveu principalmente à propaganda contra os jesuítas, segundo a qual os missionários estavam desviando a oferta de mão de obra indígena para seus próprios propósitos. Assim, na segunda metade do século XvIII, ficou decisivamente abalada a confiança no papel da Igreja, tanto ideologicamente diante do Iluminismo e seus "philosophes", quanto como mediadores entre o europeu e os povos nativos da América.

Logo, não é de surpreender que houvesse algum tipo de tentativa de reafirmar o valor da contribuição eclesiástica para a colonização, e Santa Rita Durão parece ter sido um personagem suficientemente extraordinário para encarar a tarefa. Depois de ter se tornado um respeitado doutor em filosofia e teologia em Portugal, a ambição o levou a consolidar uma amizade com d. João Cosme, o Bispo de Leiria, com cuja influência ele esperava contar. Com esse propósito ele escreveu a Pastoral, a mais violenta investida contra os jesuítas até o momento, que foi publicada no nome do bispo. Entretanto, como pagamento pelos serviços de Durão, o bispo tomou todo o crédito para si, abandonando seu protegido. Durão passou vários anos viajando pela Europa recuperando-se dessa ingratidão, perseguido por um terrível sentimento de 
culpa que o levou a marcar uma audiência com o papa e a publicar a Retractação de suas calúnias anteriores (publicada em Viegas, 1914). ${ }^{12}$

O poema Caramuru pode ser visto como uma tentativa renovada de expiar sua culpa: desse modo é possível explicar o retrato que Durão faz de Diogo Álvares como o precursor dos missionários jesuítas através de um enorme exagero de sua influência religiosa sobre os índios. Durão constrói toda uma mitologia messiânica em torno da chegada de Diogo, combinando lendas existentes com algumas de sua própria invenção: a passagem da Ilha do Corvo conta como São Áureo foi transportado miraculosamente a uma terra distante e desconhecida para trazer a Palavra de Deus a Guaçu, um moribundo, que já havia sonhado com a visita do "Homem com barbas, branco, e venerando" (Canto I, XLVIII). ${ }^{13}$ Esse homem comprovaria sua fé na salvação do homem de sua condição humana: "Mas nunca duvidei que alguém se visse,/ Que de tantas misérias nos remisse" (Canto I, XLIX). À beira da morte o velho é colocado na ilha para apontar o caminho do "paiz do metal rico" - as referências ao Brasil são evidentes e há um convite claro à identificação entre São Áureo e Diogo Álvares, cuja chegada é antecipada no inconsciente coletivo indígena. No Canto III, o chefe Gupeva expõe uma série de conceitos teológicos - o demônio, o inferno, o pecado, um onipotente Deus da verdade - que têm pouca relação com o que se conhece da cultura indígena antes de seu contato com o catolicismo. ${ }^{14}$ De acordo com Durão, essas crenças foram transmitidas de geração a geração em formas irreconhecíveis, obscurecendo ou apagando seus verdadeiros significados ou (ver estrofe LXXX) suprimindo-as deliberadamente em casos em que elas entravam em conflito com costumes nativos pecaminosos: "Mas ignoramos hoje a que ela obriga,/ Porque os nossos maiores, pouco crentes,/ Achando-a de seus vícios inimiga,/ Recusaram guardá-la, malcontentes". Gupeva se refere à lenda duvidosa de Sumé, um visitante profético, cuja associação com São Tomé Durão explora ao máximo, sugerindo que a chegada de Diogo é o cumprimento da promessa de retorno de Sumé.

A distorção mais aberrante da cultura indígena se encontra na explicação do nome Caramuru: embora a falsa etimologia do "homem de fogo" já fosse corrente, Durão

VIEGAS, Artur. O poeta Santa Rita Durão. Revelações históricas de sua vida e do seu século. Brussels: L'edition d'Art Gáudio, 1914.

13 SANTA RITA DURÃO, José de. Caramuru, poema épico do descubrimento da Bahia. Lisboa: Regia Officina Typografica, 1781; Caramuru. Ed. by Hernani Cidade. 2. ed. Rio de Janeiro: Agir, 1961.

14 Ver, por exemplo, LÉRY, Jean de. Histoire d'un voyage fait en la terre du Brésil,autrement dit Amérique. Lausanne: Bibliothèque Romande, 1972.

312 - TREECE, David. Caramuru, o mito: conquista e conciliação 
lhe dá um significado muito específico - o "filho do trovão". Ele perpetua, assim, uma das falácias mais amplamente propagadas sobre as crenças indígenas, a saber, que Tupã - "origem ou mãe do trovão" - foi o criador divino supremo na tradição das religiões europeias. ${ }^{15}$ Assim, como o Filho desse Deus, Diogo se torna uma espécie de Cristo que teria chegado para revelar a verdadeira natureza da religião indígena, isto é, que ela é simplesmente o catolicismo disfarçado, e para ensinar aos índios que sua recusa desse fato através da prática dos costumes indígenas é uma heresia imperdoável. Paradoxalmente, Durão faz com que seus índios ajam “como animais", porém lhes dá a capacidade intelectual para saber que eles estão no caminho errado; durante a preparação do ritual de canibalismo de dois índios Caetés no Canto v, Diogo tenta libertar um dos prisioneiros, mas ele prefere ser morto, expressando outro conceito estranho ao mundo nativo, ou seja, a separação entre espírito e matéria: "o espírito, a razão, o pensamento/ Sou eu, e nada mais: a carne inmunda/ Forma-se cada dia do alimento" (estrofe LXIII). Durão condena os índios por sua própria condição, pois a ignorância não é uma desculpa aceitável:

Tornai a culpa a vós; e a vós somente

(o Heroe responde assim) Se com estudo

Procurais sobre a Terra o bem presente,

Porque não procurais o Author de tudo?

Para o mais tendes lume, instincto, e mente;

Somente contra Deos buscais o escudo

Essa ignorancia he crime, e não desculpa.

(estrofe $\mathrm{x})$

O poema de Durão se tornou o objeto de uma discussão literária daqueles críticos, notadamente estrangeiros, interessados nas teorias sobre o romantismo e na formulação de uma estética apropriada ao país recém-independente. François Eugène Garay de Monglave, Ferdinand Denis e Daniel Gavet citaram o Caramuru por seu cenário e assunto nativos como um exemplo de uma literatura distintamente brasileira mesmo antes da separação política de Portugal. Monglave era amigo de d. Pedro I e estava

Para uma análise detalhada do termo, ver: CÂMARA CASCUDO, Luís da. Dicionário do folclore brasileiro. 3. ed., Rio de Janeiro: Edições de Ouro, 1972, p. 882; e GREGÓRIO, Irmão José. Contribuição indígena ao Brasil. 3 vols. Belo Horizonte: União Brasileira de Educação e Ensino, 1980, III, p. 1185-9.

Teresa revista de Literatura Brasileira [12|13]; São Paulo, p. 307-344, 2013 • 313 
convencido do valor não reconhecido da literatura portuguesa e brasileira e de seu lugar merecido na tradição europeia, considerando o Caramuru e O Uraguai como comparáveis ao O último dos moicanos de Fenimore Cooper. Para remediar a situação ele planejava a tradução de vinte obras portuguesas e brasileiras para o francês, dentre as quais a tradução do Caramuru era a única a ser levada a cabo. Essa tradução teve um papel importante, incentivando uma abordagem romanesca dos temas indígenas, pois, ao adotar a prosa no lugar do verso, ao suprimir certas passagens de natureza mais formal e convencional e ao reestruturar os dez cantos do poema em trinta e dois episódios de tamanho variável, ele abandonou o tom e o ritmo épicos de Durão e adotou um gênero intermediário descrito por Monglave como roman-poème.

Ferdinand Denis foi reconhecido como uma influência vital na adoção do índio e da paisagem nativa como elementos centrais para uma literatura verdadeiramente nacional no Brasil. Em seu Résumé de l'histoire littéraire du Brésil, ele expressou admiração limitada pelo poema de Durão, fazendo uma distinção importante entre o poema e o mito que lhe havia servido de inspiração: "lévènement le plus poétique qui suivit la découverte de ce beau pays [...] presente l'hereuse peinture du génie ardent et aventureux des Portugais de cette époque, mis en opposition avec la simplicité sauvage d'un peuple dans l'enfance" ${ }^{16}$ Para Denis, o mito do Caramuru não expressa o ideal da evangelização cultural europeia e de sua aceitação pelos índios proposto por Durão, mas a oposição estabelecida por Rousseau entre o homem civilizado e o homem natural representado pelo "povo na sua infância”. Denis também demonstra interesse pelo papel da índia Paraguaçu que, após a prisão fictícia de Diogo pelo governador Coutinho, "prit la résolution de venger son mari, et combattit ses oppresseurs. Il y avait dans ce devoûment, dans cette ardeur généreuse de haine et d'amour, de quoi produire les plus fortes impressions, et c'est avoir bien mal compris um tel sujet que de ne point sêtre proposé comme premier but de faire ressortir tout l'héroïsme de l'épouse de Diogo". ${ }^{17}$

"o evento mais poético que se segue à descoberta desse belo país [...] apresenta a feliz pintura do gênio ardente e aventureiro dos portugueses dessa época, em oposição à simplicidade selvagem de um povo na infância". DENIS, Jean Ferdinand. Résumé de l'histoire littéraire du Portugal suivé du Résumé de l'histoire littéraire du Brésil. Paris: Lecointe et Durey, 1826, p. 534. Ver também: CANDIDO, Antonio. “Estrutura literária e função histórica". In: Literatura e sociedade. São Paulo: Companhia Editora Nacional, 1967, p. 193-220.

17 "decide vingar seu marido e combater seus opressores. Havia nessa devoção, nesse ardor generoso de ódio e de amor, elementos para suscitar as mais fortes impressões, e é ter bem mal compreendido um tal sujeito que não se propôs como primeiro objetivo fazer sobressair todo o heroísmo da esposa de Diogo". DENIS, Jean Ferdinand. Résumé de l'histoire littéraire du Portugal suivé du Résumé de l'histoire littéraire du Brésil. Op. cit., p. 553.

314 • TREECE, David. Caramuru, o mito: conquista e conciliação 
Jakaré-Ouassou, ou les Tupinambás, Chronique Brésilienne (1830) desenvolve ambos os elementos relacionados à versão do mito descritos por Denis, baseando-se amplamente na tradução de Monglave, publicada no ano anterior. Seus autores, Daniel Gavet e Philippe Boucher, foram descritos por Antonio Candido como "dois jovens de ínfima categoria literária"; e, de fato, há uma ausência surpreendente de informações sobre ambos. Só se sabe que Gavet (1811-67) viveu no Brasil e no Uruguai entre 1818 e 1825 e que aprendeu português e espanhol. Mais tarde ele traduziria diversas obras para sua língua nativa e publicaria cinco livros, incluindo Zaccaria, anecdote brésilienne e Jakaré-Ouassou. ${ }^{18}$

O romance desloca a parte central do mito do Caramuru (a integração de Diogo entre os índios e seu casamento com Paraguaçu) para o pano de fundo histórico. O mito de Caramuru como o arquétipo do colono ideal é mantido, já que são seus métodos pacíficos de trazer a "civilização" aos índios que levam Coutinho a ordenar sua prisão e que fazem os índios jurarem vingança e guerra contra os portugueses. Enquanto isso, o enredo central revolve em torno de uma tentativa de salvamento paralela àquela de Diogo por Paraguaçu, mas que, ao contrário desta, tem consequências trágicas. Durante o período em que o índio Tamanduá é prisioneiro dos portugueses, ele vê Inez, a filha do governador, e se apaixona por ela. Inez protesta em vão contra as crueldades do tratamento que seu pai dispensa aos índios e defende Tamanduá das acusações de impiedade feitas pelo padre contra ele. Entretanto, essa união em potencial do índio e da branca está fadada ao fracasso, pois Coutinho, o pai opressor, prometeu a filha a Almada, seu aliado maligno. Embora tanto Coutinho quanto Almada mais tarde sejam deixados de lado (Coutinho é vítima de um naufrágio e Almada escapa de maneira ignominiosa da batalha), Tamanduá se encontra no centro de outra relação impossível. Moema, sua amante abandonada, sucumbe fatalmente à falsa profecia do pajé sobre sua própria morte iminente, usada para aumentar o poder do pajé sobre a tribo. Enquanto isso, cabe ao velho amigo Jakaré a proteção de Inez que, durante todo o período de hostilidades, está a cargo dos índios; ele também se apaixona pela filha do governador e tem a chance de consumar sua paixão enquanto Inez jaz inconsciente, mas resiste e permanece fiel a Tamanduá. Entretanto, elementos inimigos tiram vantagem da suposta traição, convencendo Tamanduá da culpa do amigo, o que faz com que Jakaré morra inocentemente nas mãos de seu próprio povo. Num certo ponto, a verdade é revelada a 
Tamanduá, mas para compensar sua desconfiança ele morre na tentativa de salvar Jakaré do ataque de um jaguar. Sua morte é interpretada como um assassinato e a condenação do inocente Jakaré passa ao folclore indígena como uma verdade. Um epílogo reconta o triste exílio da tribo e a impotência de um padre bom, Rodrigues, contra a destruição da Conquista: "Si tous les Portugais avaient été comme toi...!' [...] Il y avait quelque chose d'horrible dans ces confidences de la douleur faites par le sauvage à l'homme civilisé: cétait comme une malédiction lancée du fond du désert ontre l'ancien monde et sés bourreaux". ${ }^{19}$

Jakaré-Ouassou realiza, portanto, uma remodelagem considerável do mito do Caramuru: desloca a relação de Diogo/Paraguaçu para o fundo; substitui essa ênfase narrativa por uma rede trágica de relações entre índios e brancos, em cujo centro e origem está a europeia Inez; procura criar uma heroína na figura de Paraguaçu e transforma Coutinho numa figura paterna opressiva. Isso tudo obviamente coloca questões importantes a respeito da aceitabilidade de um mito como o de Caramuru, que tradicionalmente representa a conciliação, por parte do movimento romântico, para o qual as relações entre "o civilizado" e o "homem natural" são normalmente trágicas (cf. os enredos de Jakaré-Ouassou e de Les Natchez, de Chateaubriand).

Francisco Adolfo de Varnhagen nasceu em 1816 no estado de São Paulo, filho de um alemão. Educado em Portugal e formado engenheiro militar, lutou na guerra civil portuguesa do lado dos Constitucionalistas contra a facção absolutista dos Miguelistas. Como resultado de sua ascendência e dessas ações, ele encontrou alguma dificuldade em estabelecer sua nacionalidade como brasileiro, e passou boa parte da vida tentando resolver esse problema. Durante sua carreira diplomática, passada principalmente na Europa, coletou material para sua monumental História geral do Brasil, para cuja publicação em Paris ele teve ajuda de Ferdinand Denis. Criticado por suas viagens de estudos à Europa por figuras como Alencar, Varnhagen estava ansioso para provar que preparava uma contribuição valiosa para o Brasil. A História geral, que era essa prova, ganhou a admiração de figuras internacionais como os exploradores Humboldt e Von Martius. ${ }^{20}$

"'Se todos os portugueses tivessem sido como você...!' [...] Havia algo de horrível nessas confidências da dor causadas pelo selvagem ao homem civilizado: era como uma maldição lançada do fundo do deserto contra o antigo mundo e seus carrascos." GAVET, Daniel; BOUCHER, Philippe. Jakaré-Ouassou, ou les Tupinambás. Chronique Brésilienne. Paris: Timothée de Hay, 1830, $364 \mathrm{f}$.

20 Ver: LYRA, Heitor. História de Dom Pedro /l (1825-1891). 2 vols. Belo Horizonte: Itatiaia, 1977, II, p. 122, a principal fonte sobre a vida de Varnhagen. 
À primeira vista, a atitude de Varnhagen em relação aos índios seria ambígua, estando associada a uma confusão generalizada a respeito das lealdades políticas de diversos escritores e personalidades públicas do período. Varnhagen era amigo do príncipe Maximilian von Neuwied, que o recomendou a d. Pedro II e conhecia Von Martius, ambos exploradores destacados e autores de narrativas importantes sobre suas viagens no interior do Brasil. No primeiro retorno ao país desde sua infância, Varnhagen apresentou ao Instituto Histórico e Geográfico Brasileiro uma carta de Von Martius agradecendo o Instituto por sua filiação. Nas palavras de Heitor Lyra, Varnhagen "aproveitou a oportunidade para falar em defesa da civilização dos nossos índios, que a seu ver estavam em perigo de se extinguir". Em 1875 ele viajou a Copenhague e trouxe à atenção de d. Pedro II as pinturas de Eckout, o artista que havia acompanhado o conde Maurício de Nassau durante a ocupação holandesa do Nordeste e cujas pinturas de índios são agora muito conhecidas.

Esses fatos sugerem um interesse pela cultura e pela condição dos índios, algo que contradiz dramaticamente as observações que ele faz na História geral (1854), observações que provocaram uma reação veemente de Gonçalves Dias, que sempre expressara admiração pelo trabalho. Após sua descrição dos costumes indígenas, que ele mesmo confessou ser pouco lisonjeira, Varnhagen faz este comentário sobre o índio e sua relação com a civilização europeia: "Desgraçadamente o estudo profundo da barbárie humana, em todos os países, prova que, sem os vínculos das leis e das religiões, o triste mortal propende tanto à ferocidade, que quase se metamorfoseia em fera.... ${ }^{21}$ Em outro momento ele justifica o tratamento repreensível dos colonos em relação aos índios e o emprego da força em sua "pacificação" e termina o capítulo com o que equivale a uma defesa da campanha sistemática de aniquilamento levada a cabo no reino de d. Pedro II. A conquista, ele afirma, foi a recompensa merecida dos índios pela sua expulsão dos primeiros habitantes da costa ocidental: "A seu turno devia chegar-lhes o dia da expiação. Veio a trazê-lo o descobrimento e colonização, efectuados pela Europa cristã. ${ }^{22}$

A contribuição de Varnhagen ao mito do Caramuru não se limita a seu papel de historiador. No final do ensaio "O Caramuru perante a História" e depois de todo seu ceticismo em relação à autenticidade da lenda como um todo, ele é incapaz de negar o quanto a história se prestava a propósitos literários e confessa a autoria de ainda outra

VARNHAGEN, Francisco Adolpho de. História geral do Brasil antes da sua separação e independência de Portugal. Op. cit., I, $52 \mathrm{f}$.

22 Idem, l, p. 56.

Teresa revista de Literatura Brasileira [12|13]; São Paulo, p. 307-344, 2013 • 317 
versão da lenda. Ele se refere a O Caramuru, Romance histórico brasileiro, publicado pela primeira vez em 1853 em sua própria antologia Florilegio da poesia brazileira ${ }^{23} \mathrm{com}$ o subtítulo de "O matrimônio de um bisavô". Embora ele não se distancie grandemente do enredo tradicional, o tom popular do poema, próximo da balada, marca uma mudança interessante de ênfase que afeta tanto a natureza social do tema da colonização, quanto a relação entre Diogo e Paraguaçu. Escrito em quadras de redondilha menor, com rimas no segundo e terceiro versos (uma forma muito próxima da balada típica do mundo hispânico), o poema começa de uma maneira que remete à narrativa popular:

Consente que eu conte,

Que o sei todavia,

Um conto d'amores

Que li noutro dia.

Ao apresentar o mito do Caramuru como "Um conto d'amores", Varnhagen solapa completamente o heroísmo tradicional de Diogo Álvares em seu papel de pioneiro e colonizador, transformando-o num marinheiro comum que se apaixona pela filha do chefe da tribo. Aturdido e aparentemente incapaz de agir por si mesmo, Diogo é salvo duas vezes por Paraguaçu das garras famintas da tribo. Grande parte do "realismo" brutal e cômico do poema parte dos problemas causados por seu caso amoroso na selva brasileira. Paraguaçu, que tem controle tanto sobre seu pai, "o valente Uivia”, quanto sobre Diogo, já está grávida e implora que seu marido seja poupado da execução. Uivia não se convence e não consegue compreender os protestos da filha:

'Não sejas tontinha'

O pai respondia;

'Dos usos antigos

Respeita a valia

Sem bailes, sem festas

A vida enfastia:

Sem vinho e moquém

Não há cortesia'. 
Como resultado Paraguaçu intervém diretamente, envolvendo seu pai numa guerra civil e ameaçando a vida de todos, até que Uivia apazigue seu povo e o casal possa reunir-se. Um exame da evolução do mito mostrará que essa mudança de tom se deve em parte às conotações históricas e contemporâneas do nome "Caramuru" para Varnhagen. $\mathrm{O}$ estilo e a forma também resultam provavelmente da tendência romântica de buscar a autenticidade artística nas formas e temas populares. Varnhagen estava certamente interessado em tais ideias - em 1858 ele trouxe a d. Pedro II um manuscrito do Cancioneiro de antigos trovadores portugueses na esperança de publicá-lo. Os elementos estilísticos apontados acima têm muito em comum com as trovas medievais e sugerem o desejo de reafirmar o estatuto tradicional do mito, algo que o autor faz também ao retomar pormenores da versão antiga, anterior a Rocha Pitta e a Santa Rita Durão. Ele confirma suas intenções numa nota ao poema no Florilegio da poesia brazileira: "na qual, além da rima aturada, como usavam os antigos, procuramos conservar a naturalidade, atributo especial deste gênero de composição, a que hoje em Portugal chamam xácaras". ${ }^{24}$ As edições do poema de 1859 e 1861 (utilizadas aqui) ${ }^{25}$ foram publicadas, nas palavras de Varnhagen, "em formato liliputiano", ou seja, numa edição pequena de apenas alguns centímetros de tamanho. Isso sugere uma tentativa de tornar o poema mais acessível ao público através da distribuição barata e fácil. Entretanto, o poema recebeu pouca atenção desde o século xIx e permaneceu em completa obscuridade. $\mathbf{O}$ tratamento dispensado por Varnhagen ao tema indianista é difícil de explicar em vista de suas atitudes contraditórias em relação aos índios de modo geral, como apontado anteriormente. José Honório Rodrigues fornece a chave do problema quando fala de uma nova classe colonialista no Brasil do século xix que estava imbuída das ideias racistas da escola alemã, às quais Varnhagen, com seus laços familiares e contato com a Europa, provavelmente não estava imune. Essa classe projetava uma imagem dupla do índio: de um lado, sua idealização literária para consumo turístico externo ("para inglês ver"), enquanto, de outro, sua presença indesejável como uma mancha racial na sociedade brasileira. ${ }^{26}$ Quaisquer que tenham sido os motivos de sua defesa inicial dos índios, os comentários públicos de Varnhagen, assim como o caráter claramente não idealizado dos índios no poema Caramuru, sugerem que ele

24 Idem, III, p. 225, n. 1.

25 VARNHAGEN, Francisco Adolpho de. O Caramuru. Romance histórico brasileiro. Rio de Janeiro: Typ. de Pinto de Sousa, 1861.

26 RODRIGUES, José Honório. Independência: Revolução e contrarrevolução. 4 vols. Rio de Janeiro: Francisco Alves, 1975, II, p. 105.

Teresa revista de Literatura Brasileira [12|13]; São Paulo, p. 307-344, 2013 • 319 
estava mais interessado no índio como um símbolo político do que em suas possibilidades literárias mais amplas no interior do drama dos valores e conflitos românticos. Além das obras e figuras examinadas acima, também farei referência a dois romances: Os herdeiros de Caramuru, de Jaguaribe Filho, e Catherine du Brésil, de Olga Obry. Eles foram escritos no final do século XIX e em meados do século $\mathrm{xx}$, respectivamente, $\mathrm{e}$ indicam que o mito do Caramuru continua a ter significado considerável para brasileiros e europeus como símbolo da história colonial brasileira, sendo capaz, portanto, de refletir atitudes variadas em relação a esse período do desenvolvimento do país.

\section{Desenvolvimento do mito}

\section{(a) Diogo e Coutinho}

Uma das primeiras referências a Caramuru é a de Gabriel Soares, na qual Diogo Álvares aparece apenas incidentalmente em associação com Francisco Pereira Coutinho, o donatário da capitania da Bahia. Coutinho confiava excessivamente na sua experiência muito diferente nas colônias portuguesas na Índia e por fraqueza ou indecisão foi deslocado pelos índios Tupinambás locais para a capitania de Ilhéus, mais ao sul, algo de que a comunidade indígena aparentemente se arrependeu:

[...] e arrependido da ruim vizinhança que lhe tinha feito, movido também de seu interesse, vendo que, como se foram os portugueses, lhe iam faltando os resgates, que lhes eles davam a troco de mantimentos, ordenaram de mandar chamar Francisco Pereira mandando-lhe prometer toda a paz e boa amizade, o qual recado foi dele festejado, e embarcou-se logo com alguma gente em um caravelão que tinha, e outro em que vinha Diogo Álvares, de alcunha o Caramuru, grande língua do gentio, e partiu-se para Bahia, e querendo estar pela barra dentro, lhe sobreveio muito vento e tormentoso, que o lançou sobre os baixos da ilha de Taparica, onde deu à costa; salvou-se a gente toda deste naufrágio, mas não das mãos das Tupinambás, que viviam nesta ilha, os quais se ajuntaram, e à traição mataram a Francisco Pereira e a gente do seu caravelão, do que escapou Diogo Álvares com os seus, com boa linguagem. ${ }^{27}$ 
Soares, Salvador e Vasconcellos enfatizam a incapacidade de Coutinho na tarefa de colonizar a Bahia e, pelo menos para os dois primeiros historiadores, Diogo parece representar uma contraparte mais eficiente, avançando em relação a seu superior social e militar. Segundo Vasconcellos, Diogo é liberto de sua associação com Coutinho para tornar-se o protagonista independente da história: "E querem alguns contallo a elle pello primeiro Povoador da Villa Velha". ${ }^{28}$ Santa Rita Durão, que indica o trabalho de Vasconcellos e de Rocha Pitta entre suas fontes no início do Caramuru, descreve o heroísmo de Diogo como parte de um plano deliberado e independente de colonização:

\begin{abstract}
Da nova Lusitania o vasto espaço
Ia a povoar Diogo, a quem, bisonho,

Chama o Brasil, temendo o forte braço,

Horrível filho do trovão medonho
\end{abstract}

(Canto I, IX)

É no século xIx que Coutinho reaparece como um elemento significativo na história do Caramuru. Em Jakaré-Ouassou ele é uma figura paterna monstruosa que obriga sua filha Inez a casar com Almada, seu terrível aliado. Essa repressão paterna é simbólica daquela exercida pelo "pai” colonial, ou seja, por Portugal, sobre seu domínio ultramarino, que luta por sua independência através da união com uma cultura que se situa fora da família patriarcal - o casamento entre Diogo/Caramuru e a indígena brasileira Paraguaçu. Esse nível de significado político está presente no romance sob a forma da história da captura de Diogo por Coutinho e da brutalidade deste último em relação aos índios. A versão francesa do Caramuru parece insistir na divergência paradoxal e no resultado de seus dois enredos. Num deles, o Caramuru consegue escapar e Coutinho sucumbe nas mãos dos índios após o naufrágio; entretanto, no segundo enredo, suas ações levam ao trágico envolvimento de Inez com os personagens indígenas e a destruição desses. O romance é, portanto, uma celebração contida da independência do tirano colonial, mas, ao mesmo tempo e com grande ênfase, um registro do dano irreparável causado pelos europeus ao espírito natural e puro do Novo Mundo.

Para Varnhagen a questão da nacionalidade brasileira também era um problema, como apontado acima, mas sua lealdade básica aos valores europeus significa que seu 
interesse pela independência é expresso em termos políticos e econômicos, mais do que como um conflito entre a "civilização" europeia e o nativo americano "natural". $\mathrm{Na}$ História geral, ${ }^{29}$ ele reproduz o documento que registra a doação que Coutinho faz de uma sesmaria a Diogo e sugere que tais presentes foram a principal causa da retirada de Coutinho em direção a Ilhéus, pois os beneficiários se tornaram autocratas dispersos, que ignoravam os pedidos do governador por unidade militar contra o ataque dos índios. Varnhagen chega a afirmar que esses colonos colaboraram com os índios locais para a expulsão de Coutinho da Bahia. Como representante de ambos os grupos, Diogo Álvares foi responsável por organizar e permitir o retorno de Coutinho, do mesmo modo que mais tarde seria indispensável na reconciliação de Tomé de Sousa com a região. Logo, para Varnhagen, Diogo/Caramuru é um rebelde político moralmente superior ao governador português fraco e inepto. Isso se confirma em seu poema, O Caramuru, em que a primeira chegada de Diogo à Bahia é causada por sua deserção da tirania do capitão do navio e no qual a missão de salvar Coutinho é um ato de misericórdia: "Valer ao bom velho,/ Que afflicto se via".

\section{(b) Diogo, o herói}

Nos diversos "enredos" do mito, há variações sobre a explicação de como Diogo escapou da morte. Na versão de Soares, a "boa linguagem" de Diogo implica que ele teria algum conhecimento prévio dos índios e certa influência sobre eles, enquanto Vasconcellos, Rocha Pitta e Southey descrevem como ele cooperou com os Tupinambás na recuperação de objetos do navio naufragado. Em todos esses casos Diogo também consegue esconder um mosquete, pólvora e munição, com os quais ele impressiona os índios ao matar um pássaro. Porém, Santa Rita Durão poupa Diogo da humilhação de cooperar em sua própria captura. Em sua versão, Diogo guarda, além da arma, uma armadura que de algum modo ele consegue esconder numa caverna. Assim, Durão faz com que a subjugação e captura do herói constituam um triunfo calculado: ele aparece com sua armadura quando a tribo de Gupeva está sendo atacada por Sergipe, "o príncipe valente", e convence os índios de que ele é o Anhangá, o espírito do mal, transformando a surpresa compreensível dos índios num terror tremulante e sub-humano: 
Enquanto a gente barbara, prostrada,

Tão fora de si está, por cobardia,

Que sem sentido, estupida, assombrada,

Só mostra viva estar, porque tremia.

(Canto II, XIII)

Novamente, Vasconcellos, Rocha Pitta e Southey são unânimes a respeito de como Diogo luta ao lado desses índios contra outra tribo, os índios Tapuias, que não falam tupi, segundo Vasconcellos. Já Durão leva o heroísmo e a superioridade cultural de Diogo ao extremo quando faz com que o ofensor Sergipe receba ajuda de uma aliança impossível de tribos, incluindo os Potiguares do Nordeste e os Carijós da região do Rio Grande do Sul. Ao reunir tribos separadas por milhares de quilômetros, representando desse modo toda a população nativa do Brasil, Durão transforma a influência local de Diogo numa conquista militar e política total do país, fazendo dele o arquétipo do colono.

\section{(c) Paraguaçu, a heroína}

Contrastando com todo esse heroísmo e superioridade intelectual masculina, Salvador e Varnhagen dão o crédito da sobrevivência de Diogo a sua salvadora. Citando Salvador: "E não sei se ainda isto bastaria pelo que são carniceiros e ficaram encarniçados nos companheiros, se dele não se namorava a filha de um índio principal que tomou a seu cargo o defendê-lo". ${ }^{\circ}$ No poema de Varnhagen, Diogo é ameaçado pelo ritual de canibalismo, que para ele é prova do abismo intelectual e cultural entre os europeus e os homens primitivos. Esse elemento também cria o cenário ideal para o ato de redenção de Paraguaçu, que assume um elemento adicional de autossacrifício que está ausente de outras versões. Grávida, ela arrisca a própria vida e a de sua criança ao intervir e bloquear o golpe fatal com força incomum:

Qual era o novo anjo,

Que assim suspendia

Um golpe fatal,

Quem não desconfia?

30 SALVADOR, Frei Vicente do. História do Brasil (1500-1627). Op. cit., p. 127.

Teresa revista de Literatura Brasileira [12|13]; São Paulo, p. 307-344, 2013 • 323 
Um anjo da terra

É, sem poesia,

A filha do forte,

Do valente Ouvia.

Na ocasião do segundo naufrágio, as versões de Salvador e Varnhagen mostram Paraguaçu salvando Diogo ao trazer o mosquete e anunciar seus poderes sobrenaturais, tirando de Diogo os últimos vestígios de autodeterminação e virilidade. A caracterização de um forte elemento nativo no casamento colonial em contraste com um elemento colonizador passivo é facilmente compreensível no contexto da independência. Uma explicação para a ênfase da força dominante de Paraguaçu no caso de Salvador talvez possa ser encontrada na natureza particular da sociedade colonial brasileira e no lugar da mulher indígena dentro dela.

Segundo Vasconcellos, que, é bom lembrar, era jesuíta, os chefes tribais ofereceram suas filhas a Diogo, que se estabeleceu como um senhor patriarcal, certamente o destino mais crível se figuras como João Ramalho eram típicas de seu tempo e de sua situação. Calmon se refere a outras versões menores nas quais é Paraguaçu quem encontra Diogo quando ele aparece pela primeira vez na praia. Porém, sua pesquisa revelou que a identificação entre essa primeira jovem e a Paraguaçu que se casa com Diogo é errônea: "É insensato (depois dos últimos documentos) confundir a índia que salvou Caramuru com a histórica Paraguaçu, mãe de famosos mamelucos, que em 1526 o acompanhou à França (numa tenacidade semelhante à da Moema lendária). A prova está em que os primeiros filhos de Caramuru, Filipa e Madalena, têm outra mãe”. ${ }^{31}$ Não é difícil compreender que o mito tenha preferido fundir as diversas parceiras de Diogo numa única figura representativa, enquanto a realidade da poligamia e da grande família patriarcal permanece firmemente presa a seu significado básico. Ao invés de contradizer essa realidade nas primeiras versões, Paraguaçu se torna sua ideia símbolo, "a mais querida de suas mulheres, dotada de formosura, e Princesa daquella gente". ${ }^{32}$ Além disso, todas as versões do mito de Caramuru, com exceção da de Durão, atribuem o papel da evangelização exclusivamente a Paraguaçu: sua visão da Virgem leva à descoberta de uma caixa que contém uma imagem para a qual o casal levanta uma capela e uma abadia. Os primeiros cronistas eclesiásticos como Salvador e Vasconcellos viram Paraguaçu como o símbolo ideal do índio 
convertido e como a concretização da ética católica no interior da família colonial. Essa influência religiosa constante do elemento feminino na família dependeu de uma aliança, tanto no mito quanto na realidade, entre a estabilidade moral da mulher e seu papel como procriadora.

Uma nota da edição da Martins de Notícias do Brasil, de Soares, ${ }^{33}$ conclui que o nome Paraguaçu não aparece em nenhum dos documentos a respeito da colonização da Bahia e que ele foi tomado por Vasconcellos de um nome de lugar. A escolha, entretanto, não foi causal, pois é o rio Paraguaçu que corre até a Bahia de Todos os Santos. A mulher indígena de Diogo tem, assim, um significado simbólico óbvio, apontando para o aspecto nativo da própria colônia, mas é possível sugerir outro nível de significado se lembramos que a palavra tupi "Paraguaçu” pode ser traduzida como "água grande”. Um exame rápido do mapa do Brasil revela que o prefixo mineral ita- e o aquático para-são os dois elementos toponímicos mais comuns do país. Gilberto Freyre ${ }^{34}$ apontou a importância dos rios na paisagem brasileira, estabelecendo uma distinção entre aqueles de pequena escala, que podem ser controlados para fins de transporte e agricultura, e os grandes rios, cujo drama e grandiosidade estão associados às expedições pioneiras dos bandeirantes e dos missionários no interior do país. As implicações geográficas do nome convidam à conclusão de que Paraguaçu é simbólica da paisagem brasileira em seu aspecto mais formidável e indomável e que uma das conquistas mais notáveis do colono foi o domínio sobre a criatura nativa.

Outra conotação relevante do rio é a da fertilidade, em termos coloniais o atributo mais importante da mulher indígena e, depois dela, da escrava negra. O reconhecimento de Salvador quanto ao papel vital da mulher indígena na família colonial pode explicar seu retrato de Paraguaçu como uma contraparte matriarcal em potencial em relação à figura de Diogo. Sua longevidade social é enfatizada pelo fato de que ela sobrevive ao marido, e Salvador parece ser forçado a dar a ela maior importância a despeito dele mesmo:

E ela alcancei eu, morto já o marido, viúva mui honrada, amiga de fazer esmolas aos pobres e outras obras de piedade [...] Morreu muito velha e viu em sua vida todas as suas filhas e algumas netas casadas com os principais portugueses da terra, e bem o

33 SOARES DE SOUZA, Gabriel. Notícia do Brasil. Op. cit, I, 1, p. 247, n. 1.

34 FREYRE, Gilberto. The masters and the Slaves (Casa-grande \& senzala). A study in the development of Brazilian civilization. Transl. by Samuel Putnam. New York: Alfred A. Knopf, 1970, p. 34-6.

Teresa revista de Literatura Brasileira [12|13]; São Paulo, p. 307-344, 2013 • 325 
mereciam também por parte de seu progenitor Diogo Álvares Caramuru, por cujo respeito fiz esta digressão. ${ }^{35}$

Seguindo cronologicamente o desenvolvimento das versões, a poligamia do mito é gradativamente atenuada e a natureza exclusiva da relação de Diogo com Paraguaçu é proporcionalmente enfatizada: na versão de Rocha Pitta, os índios mais importantes oferecem suas filhas a Diogo como concubinas, enquanto o chefe oferece sua própria filha como esposa; na versão de Southey, "os chefes ficariam contentes se ele aceitasse suas filhas como esposas". ${ }^{36}$ A recusa mais óbvia da poligamia original do mito está no poema de Santa Rita Durão - partindo da perspectiva tipicamente católica do autor, a paixão incipiente de Diogo por Paraguaçu é controlada por uma racionalidade religiosa, um conceito fundamental para a visão do autor do homem civilizado em sua superioridade em relação ao indígena brutal. Consequentemente, as considerações de Diogo sobre a ideia do casamento não poderiam ser mais pedestres: "Que pode ser? Sou fraco; ela é formosa.../ Eu livre... ela donzela... Será esposa” (Canto II, LXXXIV). Após ter ajudado Gupeva a vencer a aliança de tribos, as filhas dos chefes vencidos lhe são oferecidas. Um editor do poema explica a reação exemplar de Diogo de modo sucinto: "Os chefes indígenas oferecem as filhas a Diogo Álvares, para se honrar com o seu parentesco. O lusitano aceita o parentesco, mas não as donzelas, por casta fidelidade a Paraguaçu”. ${ }^{37}$

\section{(d) Moema}

O aspecto dessa relação entre o homem branco e o índio que mais capturou a imaginação daqueles envolvidos com o mito gira em torno da partida de Diogo para a Europa num navio francês. Na versão de Salvador em que, de modo único dentre as primeiras versões, é Paraguaçu quem toma a iniciativa (é ela que exerce a atração erótica sobre Diogo e não o contrário), Diogo embarca e a jovem, Luisa Álvares, nada para se juntar a ele. Rocha Pitta desenvolve essa ideia de sacrifício e dedicação heroica da indígena por seu mestre branco: "trocou pelas prisões do amor, pelas contingências da fortuna e pelos perigos da vida, a liberdade, os paes e o domínio, e 
lutando com as ondas e com os cuidados, o seguiu ao batel". ${ }^{8}$ Porém, Vasconcellos é o primeiro a transferir a imagem da indígena em perseguição a Diogo da figura de Paraguaçu para suas outras "esposas" ou concubinas, transformando assim a noção de sacrifício e dedicação na noção de ciúme, abandono e desespero. Em sua versão, Diogo leva sua esposa favorita consigo, enquanto, dentre as outras, pelo menos uma se afoga na tentativa de segui-lo. Assim como a ajuda de Diogo na vitória dos Tupinambás locais sobre as outras tribos simboliza a submissão política dos índios, também a imagem das filhas dos chefes implorando para serem aceitas como esposas de Diogo sugere uma submissão sexual e social. A capacidade de Diogo de rejeitar todas com exceção da que tem mais prestígio social, a saber, a "princesa" da tribo, enfatiza seu comando sobre os índios.

Entretanto, os elementos de ciúme, abandono e desespero implicam algo bem diferente na versão de Durão, pois ele é o primeiro a encontrar um significado racial na morte da jovem que se afoga, a quem ele chama de Moema. Consideremos a descrição que Durão faz de Paraguaçu:

Paraguaçu gentil (tal nome teve),

Bem diversa de gente tão nojosa,

De cor tão alva como a branca neve,

E donde não é neve, era de rosa.

(Canto II, LXXVIII)

Durão enfatiza o fato de que Paraguaçu não é como as outras índias tanto física quanto moralmente. Seu emprego dos termos "certa dama gentil brasiliana", "donzela" e "a bela americana" no lugar de "índia" ou "gentia" é indicação desse esforço. Ela tem a sensibilidade de uma "civilizada" e por isso rejeita os avanços de Gupeva, pois "Nada sabem de amor bárbaras gentes,/ Nem arde em peito rude a amante chama" (Canto II, LXXX). Já seu conhecimento de português, que ela aprende devido à presença conveniente de um prisioneiro da tribo, a aproxima culturalmente de Diogo. Antonio Candido ${ }^{39}$ corretamente vê essa transformação racial como parte de uma união cultural ideal entre a Europa e a América, na qual o português Diogo aprecia as maravilhas do Brasil, enquanto a índia Paraguaçu fala pela civilização. Entretanto,

ROCHA PITTA, Sebastião da. História da America Portugueza desde o anno de mil e quinhentos do seu descobrimento até o de mil e setecentos e vinte e quatro. Op. cit., p. 30. 
acredito que isso seja apenas parte da verdade e gostaria de propor que a Paraguaçu de Santa Rita Durão seria uma branca europeia disfarçada. Sua recusa em aceitar o fato histórico da miscigenação, algo fundamental para a história de Caramuru, faz com que ele recuse o sangue indígena e escuro de Paraguaçu, descrevendo, assim, o que é efetivamente o casamento entre duas pessoas brancas. Por outro lado, ele projeta a sensualidade perigosa e morena da índia na figura fictícia de Moema, que se agarra com esperança no casco do navio, num derradeiro gesto sexual altamente simbólico. Durão não nega a existência da atração que a proibida indígena exerce sobre o europeu; de fato, ele indica no poema que Diogo não estava imune a essa atração - Moema reclama que ele havia reconhecido sua sexualidade de modo casual e descompromissado, apenas para rejeitá-la no final:

Bem puderas, cruel, ter sido esquivo,

Quando eu a fé rendia ao teu engano;

Porém, deixando o coração cativo,

Com fazer-te a meus rogos sempre humano,

Fugiste-me, traidor, e desta sorte

Paga meu fino amor tão cruel morte?

(Canto vi, Xxxix)

A morte de Moema significa para Durão a impossibilidade moral de qualquer relação real ou socialmente reconhecível entre o homem branco e a mulher indígena, numa recusa tipicamente moralizante do fato histórico. $\mathrm{O}$ ataque verbal de Moema contra Paraguaçu está repleto do antagonismo racial que, para Durão, representa um abismo insuperável:

Por serva, por escrava, te seguira,

Se não temera de chamar senhora

A vil Paraguaçu, que, sem que o creia,

Sobre ser-me inferior, é néscia e feia

(Canto VI, XL)

Essa interpretação da relação entre Moema e Paraguaçu é confirmada no século XIX pelo romance Jakaré-Ouassou, cujos autores desenvolvem a figura trágica de Moema para fins literários diferentes. Neste caso, sua rival não é Paraguaçu, mas 
Inez, uma mulher explicitamente branca, que assume a pureza divina e o papel de salvadora da Paraguaçu de Durão, inspirando uma adoração claramente religiosa em Tamanduá, o amante de Moema. Essa polarização entre uma mulher mais escura e perigosamente sensual e seu oposto, a mulher clara e pura, é um motivo bem conhecido da literatura ocidental do período romântico, reaparecendo num contexto indianista nas personagens Isabel e Ceci, em O guarani, e em Cora e Alice, em $O$ último dos moicanos, de Cooper. Para Durão essa polarização indica padrões morais e religiosos prescritivos para o contato social, do qual a mulher exótica e não cristã deve ser excluída. Porém, para os românticos ela é sintomática do desejo europeu de escapar do convencionalismo dos sentimentos e do racionalismo sufocante da “civilização" para gozar a experiência de uma paixão "natural”. Essas "mulheres escuras" são invariavelmente vítimas trágicas, não de sua raça, mas do encontro entre o homem civilizado e seu ideal natural impossível. Moema não é amaldiçoada porque é índia - na verdade, seu amante também é um índio -, mas porque a ordem natural é interrompida pela civilização na forma de Inez.

Essa interpretação romântica da figura de Moema - o nome quer dizer "a débil ou desfalecida, a exausta pelo cansaço", segundo uma fonte ${ }^{40}$ - sobrevive no final do século XIX numa forma um tanto obscura, mas ainda assim reconhecível. No romance Helena (1876), de Machado de Assis, o nome Moema é dado ao cavalo da heroína e, por extensão, à própria Helena. O curso natural de seu amor por Estácio, em cuja casa ela vive como uma agregada, é obstruído pela crença falsa de que ela é irmã de Estácio, a filha não legítima de seu pai morto. Essas complicações, assim como sua posição social dúbia, impedem o casamento dos protagonistas, e Helena (Moema) morre. O emprego simbólico que Machado faz dos nomes em outros casos sugere que a escolha de Moema aqui não foi arbitrária e que o mito da mulher tragicamente abandonada sobreviveu a seu contexto indianista original.

A versão mais recente do mito é Catherine du Brésil. Filleule de Saint-Malo (1953), de Olga Obry, que, como o título indica, desvia a atenção de Diogo para se concentrar na figura de sua esposa (Paraguaçu / Catherine) e na importância de sua viagem à Europa. Utilizando diversos dos textos examinados aqui, assim como uma boa dose de imaginação, a autora procura reconstruir os eventos da vida da protagonista da perspectiva da psicologia feminina, mas sem abandonar as imagens de seu folclore. Grande parte da narrativa se volta para a experiência da viagem marítima e o choque psicológico da cultura europeia para uma indígena, e, portanto, se situa fora do 
escopo deste ensaio. Entretanto, certos pormenores da primeira parte do enredo são de relevância direta, especialmente aqueles que descrevem a relação entre Paraguaçu e a personagem fictícia Moema.

É interessante que a autora retome as linhas estabelecidas por Durão no século XVIII, fazendo com que Paraguaçu seja uma exceção em relação ao restante da tribo e, portanto, preparando-a para os eventos subsequentes do mito, como se eles fossem predestinados. Num capítulo intitulado "un nom est un destin", sua beleza incomum e personalidade agitada são explicadas:

Sans doute, cette foi, ils [les sages] sétaient trompés em présageant que Paraguassú serait calme, puissante e féconde comme une mer ou un grand fleuve poissonneux. De l'eau, elle avait surtout l'inquiétude, la mouvante curiosité d'un au-delà inexistant, le grand sourcier $d u$ village, pour justifier l'erreur, avait expliqué que cela venait de ce que son père avait omis de lui écraser le nez avec son pouce, dès la sortie du premier bain, comme l'exigeait formallement l'usage. Grace à cette omission fatale, Paraguassú était plus jolie que ses compagnes, d’une beauté un peu troublante par la singularité de ne pas être deformée..$^{41}$

O romance informa o leitor que, quando criança, ela participou da preparação de um ritual de execução de um prisioneiro inimigo, mas fugiu aterrorizada do ato de canibalismo, revoltada pela ideia de comer carne humana. Como a Paraguaçu de Durão, ela tem uma pureza moral ocidentalizada, acompanhada por uma inocência sexual que a faz sonhar que não é um homem, mas um pássaro de fogo que visita as mulheres e faz com que elas tenham uma criança: "Elle decide de ne pas épouser un homme, d'attendre l'arrivée de l'oiseau enchanté". ${ }^{2}$ Sua conversão ao cristianismo, efetuada por Diogo, possui um tipo de justiça mítica que caracteriza a cultura nativa como severa e masculina e a cultura europeia como suave e feminina:

"Sem dúvida, desta vez, eles [os sábios] se haviam enganado ao prever que Paraguaçu fosse calma, poderosa e fecunda como um mar ou um grande rio cheio de peixes. Da água ela possuía, sobretudo, a inquietude, a curiosidade tocante de outro mundo inexistente. $O$ grande bruxo do vilarejo para justificar o erro explicou que isso advinha do fato de que seu pai se havia esquecido de apertar seu nariz com o polegar na saída do seu primeiro banho, como exigia formalmente o costume. Graças a essa omissão fatal, Paraguaçu era mais bonita que suas companheiras, de uma beleza um pouco perturbadora, pela singularidade de não ser deformada." OBRY, Olga. Catherine du Brésil. Filleule de Saint-Malo. Paris; Nouvelles Éditions Latines, 1953, p. 20. 
[...] c'est Toupan qui est vaincu par la Vierge Marie, le dieu brutal, insensible et inaccessible, vaincu par une faible femme, la mère d'un petit enfant, qui connait toutes les souffrances et permet quion lui parle.43

Enquanto isso, Moema, um ser sensual e apaixonado, é condenada a ser abandonada e morrer no esquecimento, não devido a qualquer compulsão trágica como nas outras versões anteriores, mas porque ela é moralmente inferior a Paraguaçu. Oito anos mais velha que sua rival, ela gosta de carne humana e "passait pour être très gourmande". ${ }^{44}$ Moema se rebela contra a lei tribal que dita que uma jovem deve nomear seu primeiro amor, aquele que rompe as linhas simbólicas da virgindade que ela veste ao redor da cintura. Ao contrário, ela fica em silêncio. Quando os homens da tribo pescam um cardume de "hommes marins ou poissons à face humai$n e$ ", ${ }^{45}$ ela desaparece, mantendo um dos homens-peixes, Diogo Álvares, cativo em segredo, alimentando-o e se entregando a ele até que o esconderijo é descoberto. Diogo impressiona os índios com o modo tradicional e tem permissão para se casar com Moema, que se torna sua esposa por alguns anos. Mas com o passar do tempo ela envelhece e seu marido se torna infiel e letárgico, revivendo seu entusiasmo pela vida somente quando a jovem e inocente Paraguaçu começa a demonstrar interesse por ele e por suas terras. Logo, a iniciativa, tanto de um tipo sexual quanto mais tarde de natureza histórica, é em ambos os casos atribuída à personagem feminina e não a Diogo, que aparece como um homem arrogante e distante, preocupado apenas com o poder. Embora a autora não valorize o aspecto brutal do colonialismo europeu, ela, entretanto, parece defender o princípio do colonialismo como uma missão civilizadora historicamente inevitável. De modo significativo, seu representante ideal no caso do Brasil não é Diogo Álvares, mas sua esposa Paraguaçu/Catherine e seu rei:

Deux volontés conscientes de leur mission préparent, à la veille de 1530, le Brésil futur: cette mère qui élève ses filles et les enfants de sés rivales pour qu'un jour ils deviennent chrétiens et civilisés, et le roi Dom João III qui choisit un homme et ses auxiliaires, rédige des ins-

43 "Tupã foi vencido pela Virgem Maria, o deus brutal, insensível e inacessível, vencido por uma frágil mulher, a mãe de uma pequena criança, que conhece todas as penas e permite que falemos com ela." Idem, p. 47. 44 "dava a impressão de que gostava de comer bem". Idem, p. 29.

45 "homens marinhos ou peixes com rosto humano." 
tructions et arme des bateaux, afin de lancer les fondements de la colonisation, veiller à la défense de la côte du pau-brasil, l'explorer et expulser les corsaires étrangers. ${ }^{46}$

\section{(e) "O homem do fogo"}

Mais do que qualquer outro aspecto da história, o significado do nome Caramuru deu origem a diversas discussões e explicações totalmente divergentes. José Gregório ${ }^{47}$ coletou materiais dessa discussão e cita dezoito fontes que incluem escritores, historiadores e etimologistas. Vasconcellos é explícito ao fazer a relação entre o nome e o tiro do mosquete: "o homem de fogo (que assim lhe chamarão) que de longe feria, e matava, quaes se virão a furia de hum Vulcano, ficarão desmaiados, e derão a fugir pellos mattos, ficando assi provado o valor, e arte mais que humana (na opinião desta gente) de Diogo Álvares, [...] e aqui lhe acrescentarão o nome, chamandolhe o grande Caramuru" ${ }^{48}$ A reputação de Diogo como um ser sobrenatural é confirmada por Rocha Pitta, embora ele prefira a explicação "Dragão que sai do mar". Como apontei, Santa Rita Durão retoma a versão de Vasconcellos, pois ela corresponde mais de perto à sua imagem épica e messiânica de Diogo. Entretanto, Gregório esclarece o erro de todas essas explicações, que não possuem alguma base etimológica. Na verdade, a palavra se refere à "moreia", um habitante de água salgada que mede até $1,5 \mathrm{~m}$ de comprimento. Essa origem só se torna completamente aceita por fontes importantes do século xIX, tais como Varnhagen e Veríssimo. Apesar de Pedro Calmon concordar com a interpretação verificável, existem pelo menos dois exemplos da literatura infantil do século xx que perpetuam o mito do "homem de fogo". ${ }^{49}$ Ambas trazem ilustrações que presumivelmente representam a origem do nome e, logo, a essência da "Lenda do Caramuru": a figura de Diogo Álvares

46 "Duas vontades conscientes de sua missão preparam, nas vésperas de 1530, o Brasil futuro: essa mãe que cria seus filhos e as crianças de suas rivais para que um dia eles se tornem cristãos e civilizados, e o rei D. João III que escolheu um homem e seus auxiliares, redigiu as instruções e armou seus navios a fim de lançar as fundações da colonização, de tomar conta da defesa do pau-brasil, de explorá-lo e de expulsar os corsários e estrangeiros." Idem, p. 89.

47 GREGÓRIO, Irmão José. Contribuição indígena ao Brasil. Op. cit., II, p. 555-8.

48 VASCONCELLOS, Simão de. Chronica da Companhia de Jesu do Estado do Brasil. Op. cit., p. 38.

49 "O Caramuru". In: MARIN, Álvaro. Meu Brasil (Biblioteca Infantil de "O Ticotico"; Rio de Janeiro, 1933), e PEIXOTO, Vicente. Coração infantil (7. ed., São Paulo, 1938), ambos reproduzidos em GREGÓRIO, Irmão José. Contribuição indígena ao Brasil. Op. cit., p. 558. 
atirando com seu mosquete, enquanto os índios estupefatos fogem aterrorizados. Parece que os brasileiros preferem essa explicação porque ela se aproxima mais de sua ideia da colonização brasileira: a domesticação de um país e de um povo selvagem por heróis pioneiros e por uma tecnologia branca superior. A predominância do mito do "homem de fogo" é imediatamente compreensível se considerarmos os tons pouco heroicos e bastante irônicos do verdadeiro significado do Caramuru, o "homem moreia".

\section{3. “Os Caramurus da Bahia”}

Um aspecto da história que requer considerações mais profundas é a natureza civil da colonização da Bahia e sua história subsequente, à qual todas as versões se referem de algum modo. Já procurei demonstrar como a poligamia do mito foi sendo gradativamente negada e como Salvador foi o primeiro a reconhecer a importância de uma prole prolífica para a sociedade patriarcal da colônia. Outro traço importante dessa sociedade que os escritores expressaram através do mito é sua base aristocrática - Caramuru é em parte uma justificativa da linhagem (não substanciada) da aristocracia baiana. Vasconcellos é um dos primeiros a tentar estabelecer uma ascendência aristocrata para Diogo, "natural da notavel villa de Vianna, de gente nobre", ${ }^{\circ} \mathrm{e}$, portanto, para toda a futura classe dirigente da Bahia: "que deste tronco procederão muitas das melhores e mais nobres famílias da Bahia". ${ }^{11} \mathrm{Na}$ maioria das versões, a viagem à França e a consagração do casamento por um casal real, além do batismo de Paraguaçu com o nome da rainha (Catarina), conferem maior prestígio social e autenticidade aristocrática à família que fundou a Bahia. A aristocracia de Diogo encontra par na de Paraguaçu, que é considerada a "princesa” da tribo. Antonio Candido faz a observação importante de que o fato inegável da mestiçagem do branco e do índio levou ao mito da nobreza indígena para preservar a pureza de sangue necessária à aristocracia colonial. ${ }^{52}$ Aqui ele se refere ao tom da versão de Rocha Pitta, mas significativamente o tema da nobreza de Diogo já começa no século XVII com Salvador e Vasconcellos. Temos prova das pretensões sociais da elite baiana e de sua preocupação com a linhagem nos três poemas satíricos escritos no mesmo

50 VASCONCELLOS, Simão de. Chronica da Companhia de Jesu do Estado do Brasil. Op. cit., p. 37.

51 Idem, p. 40.

CANDIDO, Antonio. "Estrutura literária e função histórica". In: Literatura e sociedade. Op. cit., p. 199-201.

Teresa revista de Literatura Brasileira [12|13]; São Paulo, p. 307-344, 2013 • 333 
século por Gregório de Matos, Aos principais da Bahia chamados os Caramurus. ${ }^{53}$ Dos dois sonetos reproduzidos aqui, o primeiro reflete e rebaixa as pretensões dos "chefes" da nobreza mestiça da Bahia satirizando o prestígio e o caráter exótico do vocabulário tupi que eles adotam; por outro lado, o segundo faz uma paródia da preocupação com a linhagem nobre ao sugerir que a única aristocracia das baianas foi aquela "digerida" no canibalismo de seus antepassados:

Há coisa como ver um Paiaiá

Mui prezado de ser Caramuru

Descendente do sangue de tatu,

Cujo torpe é Cobepá?

A linha feminina é Carimá

Muqueca, pititinga, caruru,

Mingau de puba, vinho de caju

Pisado num pilão de Pirajá.

[...]

[...]

Tenha embora um avô nascido lá,

Cá tem três pela costa do Cairu,

E o principal se diz Paraguaçu,

Descendente este tal de um Guinamá.

Que é fidalgo nos ossos cremos nós,

Pois nisso consistia o mor brasão

Daqueles que comiam seus avós.

[...].

Até o final do século anterior à Independência, portanto, a noção lendária da linhagem nobre de Caramuru e sua família foi questionada e reconfirmada. Para Varnhagen, escrevendo num período em que a liberdade do Brasil em relação aos laços coloniais era consolidada, os papéis políticos e sociais de Diogo Álvares na Bahia assumem cores diferentes. Em seus esforços para demonstrar a falsidade do relato 
da visita de Diogo e Paraguaçu à monarquia da França, Varnhagen reforça uma imagem de Diogo como um colono rebelde, o senhor independente de um universo patriarcal mestiço fora do alcance do governo europeu e, portanto, um símbolo da independência brasileira. Consequente, o historiador do século xıx lança dúvida sobre a linhagem nobre de Diogo, questionando a adição do nome "Correa" feita ao de "Diogo Álvares", sugerida por Rocha Pitta: "isto quando o Caramuru não passaria naturalmente nos seus tempos de algum miserável grumete". 54 Varnhagen o descreve como o mesmo "pobre grumete", um marinheiro comum que deserda seu navio para escapar da tirania de seus superiores:
Soffrer antes quero
Qualquer tyrannia
Que o vil contramestre
Que a mim me zurzia.

Embora esse retrato possa ser interpretado como uma fuga romântica da autoridade, um triunfo liberal sobre os representantes do regime antigo ou em termos da independência nacional, ele também combina com a natureza geral do mito do Caramuru, com Diogo como o "primeiro Povoador da Villa Velha". Entretanto, pode ser que Varnhagen tivesse razões mais imediatas para denegrir a figura do Caramuru, para além do seu desejo de enfatizar o papel nativo no mito.

José Bonifácio de Andrada e Silva tornou-se o primeiro-ministro de d. Pedro I em 1822 e foi durante vários anos o tutor do futuro herdeiro, Pedro II. Sua administração dessas tarefas continua a provocar opiniões grandemente divergentes sobre seus motivos e intenções políticas. Os defensores de Bonifácio após a independência em 1822, especialmente o jornal O Tamoio, davam aos Andradas títulos como os "Franklin brasileiros", os “Anjos Tutelares da Regeneração Política", "Pais da Pátria" e, ao próprio José Bonifácio, "Patriarca da Independência". ${ }^{55}$ Após a abdicação de d. Pedro I e a regência do Padre Feijó, as divisões entre as facções políticas se tornaram mais acentuadas. As três principais eram os liberais "moderados", os "exaltados" mais radicais e os "Caramurus" conservadores, que apoiavam a restauração de d. Pedro I. O nome deste último grupo foi emprestado de um dos diversos jornais que surgi-

\footnotetext{
54 VARNHAGEN, Francisco Adolpho de. "O Caramuru perante a historia". Revista do Instituto Histórico e Geographico Brazileiro. Op. cit., p. 143.

55 Ver: VIOTTI DA COSTA, Emílio (1979: 88-97 e em geral) para uma discussão sobre José Bonifácio.
} 
ram nessa época: "Em princípios de 1832, havia cerca de cinquenta jornais no Brasil, muitos com as denominações as mais estranhas. Ao lado da Malagueta, da Mutuca, do Jurujuba, aparecia o Filho da Terra, o Republicano da Sempre-viva, o Caramuru e o Carijó, os dois últimos francamente restauradores e obedecendo à inspiração de Martim Francisco e Antônio Carlos" (Sousa, 1957, vi: 123). ${ }^{56}$ A adoção da maioria desses nomes nativos pode ser vista como arbitrária, simplesmente uma tentativa de adquirir uma imagem de respeitabilidade diante da causa da independência. Porém, a escolha do Caramuru, não o nome de uma tribo, mas de uma figura histórica e lendária específica, parece conter maior significado simbólico. Durante o período em que José Bonifácio foi tutor de Pedro II, ele foi defendido por um dos editores do Caramuru quando acusado de conivência numa conspiração de restauração. Sua traição da causa republicana foi descrita nos termos simbólicos empregados pelos jornais que o apoiavam: “Acusava-se o antigo 'Tamoio' de se ter convertido em 'Caramuru”" (Viotti da Costa, 1979: 92). Com José Bonifácio claramente identificado como um líder do movimento de Restauração, as lealdades políticas se tornaram ainda mais polarizadas. Na edição do Aurora de 14 de julho de 1834, Evaristo da Veiga descreveu a situação da seguinte maneira: "na grande questão que nos ocupa na peleja de vida e morte, não há senão dois partidos no Brasil: chimangos ou amigos da revolução [de 7 de abril], caramurus ou inimigos dela”. A associação de José Bonifácio com o nome do Caramuru, portanto, parece significar uma posição monarquista conservadora, em apoio aos valores tradicionais da sociedade colonial patriarcal celebrada no mito e totalmente em conflito com a ideologia do liberalismo.

A chamada "versão antiandradina", que retrata José Bonifácio como um déspota ambicioso, foi em grande parte responsabilidade de membros do Instituto Histórico e Geográfico Brasileiro, particularmente o Marquês de Sapucaí, Januário da Cunha Barbosa e Varnhagen. Parece que Varnhagen também tinha motivos pessoais, pois seu pai era administrador de uma usina em Ipanema e havia sido acusado de incompetência por Bonifácio. Quaisquer que sejam os motivos, Viotti da Costa ${ }^{57}$ apontou que o retrato do "patriarca" feito por esse grupo de historiadores estava longe do seu ideal de sobriedade imparcial: tanto a emasculação de Diogo quanto a ironia em

56 SOUSA, Octávio Tarquínio de. História dos fundadores do Império do Brasil. 2. ed. 7 vols. Rio de Janeiro: José Olympio, 1957

57 VIOTTI DA COSTA, Emília. Da monarquia à república: momentos decisivos. 9. ed. São Paulo: Ciências Humanas, 1979; São Paulo: Editora da Unesp, 2010. 
relação à base aristocrática da colônia na Bahia, realizadas por Varnhagen em seus estudos históricos e também no poema, podem ter sido condicionadas pelo menos em parte por essas conotações contemporâneas do nome Caramuru.

A tendência de diminuir o estatuto tradicional de Diogo Álvares como repositório de todos os melhores valores coloniais continua até o final do século. Os herdeiros de Caramuru (1880) de Domingos José Nogueira Jaguaribe Filho é chamado de "romance histórico", embora seja mais "histórico" do que "romance". Seu autor não figura nas histórias literárias e bibliografias, e o único pormenor biográfico relevante é o fato de que ele era filho do político Jaguaribe, um colega, parente e correspondente de José de Alencar. Porém, é num contexto não indianista que essa obra deve ser situada. A cópia que consultei foi um presente de Joaquim Nabuco, figura central na campanha abolicionista no Brasil a partir dos anos 1870, a José Maria da Silva Paranhos, Visconde do Rio Branco, então primeiro-ministro e defensor da "Lei do Ventre Livre" de 1871, segundo a qual, de acordo com certas condições, todos os filhos nascidos de escravos ficariam libertos. Os herdeiros de Caramuru é uma reavaliação da história colonial e particularmente da parte sobre a fundação da Bahia sob a luz dessa questão ética.

$\mathbf{O}$ romance não muda nenhum dos detalhes tradicionais do mito do Caramuru, elogiando sua inteligência política como mediador entre o governo português e os índios, sua lealdade a Portugal, o caráter empreendedor de seu trabalho na agricultura e seu papel como pai fundador da Bahia. Entretanto, ele enfatiza um fato cuja importância todas as outras versões ignoram ou diminuem: o fato de que Diogo Álvares e sua mulher e família possuíam e negociavam escravos, tanto indígenas quanto africanos:

Só commetteu uma falta: Caramuru teve escravos, negociou com africanos, comprou carne humana! $5^{8}$

Foi em Villa Velha, na Bahia, que viveu Diogo Álvares Correia e sua mulher, e os chronistas narram que ahi ganhou fortuna grande, contando-se por centenas o número de seus escravos! ${ }^{59}$

NOGUEIRA JAGUARIBE FILHO, Domingos José. Os herdeiros de Caramuru. Romance histórico. São Paulo: Jorge Seckler, 1880, p. 95.

59 Idem, p. 18. 
Os grupos dos herdeiros imediatos de Caramuru são formados por sua prolífica prole mameluca e as famílias que eles estabeleceram com outros imigrantes portugueses. Foram eles que desenvolveram o tráfico de escravos da África como um grande empreendimento comercial: ${ }^{60}$

Devemos declarar que os portuguezes colonisadores foram os maiores possuidores de escravos; e ainda que não se possa garantir o número de filhos que o grande povoador e patriarcha Caramuru teve no Brasil, todavia sabe-se que muitos foram negociantes de pretos na África.

Também herdeira da tradição de Diogo Álvares é a sociedade brasileira do século XIX que, além de sua descendência genealógica de colonos como Caramuru, também herdou sua tradição escravista.

A esse elemento da história do Brasil e seu tecido social, o autor opõe outra tendência, positiva, cuja rememoração é obrigação dos brasileiros contemporâneos: pois grande parte do romance descreve os esforços de Madalena, a filha menos favorita de Diogo, de impedir as crueldades e injustiças cometidas por seu pai e por seu marido brutal. É ela que fornece a inspiração e o precedente para uma sociedade e um código moral modernos em que a escravidão deve ser abolida: ${ }^{61}$

Sabeis que a primeira mulher descendente de europêo que nasceo no Brasil, que foi educada e gosou da instrucção dos povos cultos, e foi gerada por um portuguez digno de veneração dos Brasileiros chamava-se Magdalena, e já nos tempos de despotismo pensou e trabalhou pela abolição da escravidão.

Quereis pois ser indignas d'ella?

60 Idem, p. 20.

61 Idem, p. 119. 


\section{4. "Caramuru" e o romantismo}

Portanto, no século xıx, uma consciência mais aguda de certos fatos da história colonial brasileira - a saber, a quase total destruição da população nativa do país, o poder local autocrático de muitas das famílias fundadoras da colônia e a escravidão - fez com que escritores modificassem ou rejeitassem a figura de Diogo/Caramuru como símbolo da nação brasileira; daí as versões de Gavet e Boucher, Varnhagen e Jaguaribe Filho. Essa mudança de perspectiva histórica encontra expressão no interior das estruturas ou enredos míticos peculiares do romantismo. Assim, é fundamental para uma compreensão do romantismo e indianismo brasileiros que se determine de que modos o enredo subjacente ao mito do Caramuru é estranho aos enredos empregados pelos escritores românticos.

Vianna Moog já apontou a semelhança evidente entre o mito do Caramuru e o de Pocahontas. ${ }^{62}$ A lenda norte-americana relata a história da jovem filha do chefe indígena Powhatan, que salva John Smith, um explorador branco, da execução ao oferecer-se ao sacrifício no lugar do prisioneiro. Pocahontas ajuda Smith a salvar uma colônia branca da fome e de ataques inimigos e viaja com ele à Inglaterra, onde ela é recebida pelo rei, a rainha e a Igreja. Entretanto, ela não se casa com Smith e só mais tarde estabelece uma família com um colono branco, algo geralmente ignorado pelo mito.

As histórias de Pocahontas e Caramuru apresentam um contraste com o mito nativo mexicano, em que o índio permanece um elemento racial e cultural importante. No México, o mito de Cortez e La Malinche se tornou uma história de violação, segundo o qual o povo mexicano é o resultado do estupro dos indígenas pelo europeu branco. ${ }^{63}$ De outro lado, os mitos mais conciliatórios do Brasil e da América do Norte, cujos povos nativos não sobreviveram em número suficiente para oferecer uma interpretação alternativa, apresentam a possibilidade de um salvador indígena na forma de suas mulheres. Desse modo, eles parecem obter um tipo de bênção indígena para a presença europeia na América, aliviando a culpa europeia pela destruição das populações locais. Esse é o papel do Hiawatha de Longfellow, que, num

62 MOOG, Vianna. Bandeirantes e pioneiros. Paralelo entre duas culturas. 3. ed. Porto Alegre: Globo, 1956, p. 102; 19. ed. Rio de Janeiro: Graphia, 2000.

63 Ver: PAZ, Octavio. El laberinto de la soledad. 2. ed. México: Fondo de Cultura Económica, 1959, para uma interpretação detalhada desse mito. 
gesto irônico e involuntário de autotraição, dá adeus ao seu povo e dá as boas-vindas ao homem branco:

But my guests I leave behind me:

Listen to their words of wisdom,

Listen to the truth they tell you,

For the Master of Life has sent them

From the land of light and morning! ${ }^{64}$

Todas as versões do Caramuru celebram o casamento de Diogo e Paraguaçu: o casamento é, naturalmente, o ritual tradicional que confirma e simboliza a harmonia e a conciliação social. No caso do Caramuru, a relação é de vontade e responsabilidade mútuas, pois o herói Diogo é o conquistador de Paraguaçu e sua sociedade, mas é, ao mesmo tempo, salvo e aceito por eles. Ao comparar os dois mitos, Vianna Moog estabelece um contraste entre o casamento brasileiro e a ausência de uma relação mais permanente no caso de Pocahontas. Ele explica que a atitude norte-americana revela uma combinação do horror que o anglo-saxão protestante sente pela miscigenação com o fato de que a colonização no Norte envolveu famílias inteiras de emigrantes europeus, o que tornava o casamento inter-racial desnecessário. Essa distância social entre o índio e o homem branco no caso norte-americano explica por que o caráter originalmente promíscuo de Pocahontas foi rápida e facilmente "limpo".

Todavia, para os brasileiros, a "tentadora morena" representada por Paraguaçu nunca foi completamente esquecida, a despeito dos esforços de Santa Rita Durão nesse sentido. $O$ fato histórico da miscigenação no Brasil não podia deixar de ser expresso num mito de fundação como é o Caramuru e, consequentemente, a noção perigosa da tentação sexual é neutralizada. Mas é no tocante às implicações sociais do mito que Paraguaçu permanece um elemento perturbador. O índio norte-americano sempre teve uma posição periférica em relação à sociedade branca e está praticamente ausente como elemento racial no perfil nacional americano - como tal ele não representa um problema para o americano, tanto de um ponto de vista moral quanto político. Porém, o mito de Paraguaçu/Caramuru é, como já apontei, uma celebração da miscigenação e, portanto, levanta a questão da relação entre europeus e as raças

64 "Mas meus hóspedes deixo para trás de mim:/ Ouçam suas palavras de sabedoria,/ Ouçam a verdade que eles contam,/ Pois o Mestre da Vida os enviou/ Da terra da luz e da manhã!", LONGFELLOW, Henry Wadsworth. The poetical works of Longfellow. London/New York: Oxford University Press, 1925, p. 272.

340 • TREECE, David. Caramuru, o mito: conquista e conciliação 
não brancas na sociedade brasileira. Não é por acaso que, ao contrário da lenda de Pocahontas, o mito do Caramuru é conhecido pelo nome de seu protagonista masculino: enquanto, de um lado, ele expressa a celebração de uma sociedade nascida da cooperação e integração das raças, de outro ele procurou, com algumas exceções dentre os escritores do século XIX, suprimir o papel do indígena para subordiná-lo à influência do conquistador branco.

Quando comparada à enorme proliferação de versões da história de Pocahontas no século XIX, ${ }^{65}$ a escassez de obras e referências ao mito do Caramuru no mesmo século é surpreendente. Esse fato é ainda mais significativo se levarmos em conta a ênfase particular dada à história. Já indiquei antes como Jakaré-Ouassou coloca o acontecimento central da história, o casamento entre Diogo e Paraguaçu, como pano de fundo, substituindo-o pelo enredo trágico das relações entre índios e brancos. Outros escritores como Varnhagen e Jaguaribe Filho examinaram seus aspectos mais negativos, dando atenção especial às personagens femininas. Gonçalves de Magalhães, autor do épico indianista A confederação dos Tamoios, faz alusão às obras de Durão e Basílio da Gama em dois poemas de seus Suspiros poéticos e saudades (1836), a obra que marcou o surgimento do movimento romântico no Brasil. Em "Um passeio às Tulherias", a presença do próprio poeta em Paris relembra a visita de Paraguaçu e Diogo (chamado simplesmente "o esposo") à Europa. Ao invés de celebrar o casamento e sua consagração pelos monarcas europeus, esses versos na verdade lamentam os efeitos da "conquista" europeia sobre um país e um povo antes inocentes. "Invocação à saudade" expressa a saudade que o poeta sente de sua terra natal na figura de duas índias que morrem separadas daqueles que elas amam: Lindoia, que comete suicídio com uma cobra venenosa enquanto seu amante morre na prisão, e Moema, afogada nas ondas do mar enquanto tenta nadar na direção do navio de Diogo: ${ }^{66}$

Tu matas, oh saudade!... As crespas ondas,

Delirante Moema, e quase insana,

Por ti ferida se arremessa... e morre...

65 Ver: YOUNG, Philip. "The mother of us all: Pocahontas reconsidered". The Kenyon Review, 24.3, p. 391-415, Gambier, Ohio, 1962

66 SILVA RAMOS, Frederico José da (Ed.). Grandes poetas românticos do Brasil. São Paulo: Edições Lep Ltda., 1949, p. 88 e 119.

Teresa revista de Literatura Brasileira [12|13]; São Paulo, p. 307-344, 2013 • 341 
O livro Le Brésil littéraire, escrito por Ferdinand Wolf em 1863 com a ajuda de Magalhães e outros escritores, traz uma visão interessante da atmosfera do romantismo brasileiro. Após o surgimento de diversos dramas sobre temas indianistas, o Conservatório Dramático Brasileiro organizou uma competição com o intuito de encorajar essa tendência. ${ }^{67}$ Isso resultou na composição de três obras baseadas em assuntos indianistas tradicionais: Lindoya, Tragédia lírica em quatro actos, de Ferreira França, Moema e Paraguaçu, de Francisco Bonifácio de Abreu, e outra peça com o título Moema. Esses títulos sugerem que, ao invés de utilizar as estruturas literárias existentes em O Uraguai e Caramuru, que trazem o "final feliz" da domesticação dos índios e do casamento entre índios e europeus, respectivamente, os escritores românticos preferiram desenvolver episódios de natureza trágica nessas obras. A existência de um "drama histórico em quatro actos, Caramuru" sem data, escrito por Eduardo Carijé Baraúna, apenas reforça a tese, pois ele nunca foi encenado. ${ }^{68}$

Para os brasileiros do século XIX, a ideia de uma harmonia racial que favorecesse brancos e índios (ou africanos) igualmente já não era histórica ou socialmente crível. Portanto, o romantismo rejeita o tema do casamento, central no mito do Caramuru, enfatizando as cenas que mostram um indígena, preferencialmente uma mulher, representando o "homem natural", como vítima dos valores e da política europeia. A conquista, simbolicamente representada pelo surgimento de um homem branco na sociedade indígena, já não é seguida pelo nascimento de uma nova sociedade colonial integrando elementos europeus e indígenas. Mais frequentemente, há uma alienação tanto dos personagens europeus quanto dos indígenas de suas sociedades e o abandono de um pelo outro, como acontece em Iracema, ou a destruição de suas sociedades pela guerra e ganância colonial, com a fuga do casal para um lugar ideal que não existe, como no caso de O guarani.

67 WOLF, Ferdinand. O Brasil literário. Trad. Jamil Almansur Haddad. São Paulo: Companhia Editora Nacional, 1955, p. 341.

68 Ver: GONÇALVES, Augusto de Freitas Lopes. Dicionário histórico e literário do teatro no Brasil. Uncompleted. Rio de Janeiro: Cátedra, 1979, III, p. 90, 201 e 229; GALANTE DE SOUSA, J. O teatro no Brasil. 2 vols. Rio de Janeiro: Instituto Nacional do Livro, 1960, II, p. 144

342 - TREECE, David. Caramuru, o mito: conquista e conciliação 


\section{Conclusão}

Durante a vida desse mito, portanto, houve uma disputa latente por dominação entre um elemento masculino europeu de superioridade intelectual, cultural e tecnológica e um elemento feminino nativo de salvação, fertilidade e independência nacional. As flutuantes atitudes históricas quanto a esses e outros aspectos podem ser explicadas nos termos de uma mudança de papel desempenhado pelos indígenas na sociedade e na cultura brasileiras.

Nos séculos XVI e XVII estabeleceu-se a importância comercial de colônias como a Bahia, a primeira capital do Brasil, e com ela um sistema de trabalho baseado em torno das missões jesuítas. A formulação coerente do mito nessa época tende a enfatizar a dominação natural do colono branco sobre o índio, a base aristocrática da classe dominante e o papel da mulher indígena como procriadora na família colonial. A maior mudança desse sistema foi a transferência do controle sobre o trabalho para os Diretórios leigos em meados do século XVIII, que sinalizou a perda completa de poder econômico e social por parte da Ordem dos Jesuítas. A tentativa de Durão de retratar a Conquista como parte do plano divino de evangelização é a última expressão de fé no papel dos jesuítas - o indígena não é tanto um fator econômico, mas uma justificativa teológica para a presença do missionário na colônia. A substituição do trabalho indígena pela escravidão negra e a influência das ideias liberais e românticas no século xIx libertam o indígena dessa importância funcional e permitem que ele passe a ser visto como vítima de práticas coloniais questionáveis. A estrutura conciliatória do mito do Caramuru, com sua ênfase no tema da salvação e do casamento, entra em conflito frontal com essa visão e é, portanto, adaptada ou rejeitada pelos escritores a partir do século XIX. Esses escritores enfatizam a alienação das duas raças, seja enfocando os aspectos trágicos e menos históricos do mito, tal como a relação entre Diogo e Moema; seja diminuindo a estatura moral de Diogo em comparação com Paraguaçu, enfatizando seu envolvimento na escravidão em oposição à caridade religiosa e à força maternal da personagem feminina; seja inventando novos mitos nos quais as relações sociais entre índios e brancos levam à destruição ou exclusão dos primeiros da nova sociedade da colônia. Os românticos, assim como outros escritores depois deles, não reconciliam os dois aspectos do mito e caráter de Caramuru: de um lado, o "homem de fogo", "filho do trovão", aterrorizando os índios e submetendo-os através da arrogância cultural e da superioridade tecnológica; de outro, o marido da princesa indígena e fundador da família colonial racialmente integrada. 
David Treece é professor do Department of Portuguese and Brazilian Studies do King's College London e autor de Exilados, aliados e rebeldes: o movimento indianista, a política indigenista e o Estado-nação imperial (São Paulo: Nankin Ed./EDUSP, 2008) e The gathering of voices: the twentiethcentury poetry of Latin America (London/New York: Verso Books, 1993), escrito em parceria com Mike González. 